\title{
Prenatal Glucocorticoids and Exogenous Surfactant Therapy Improve Respiratory Function in Lambs with Severe Diaphragmatic Hernia Following Fetal Tracheal Occlusion
}

\author{
MARCUS G. DAVEY, ENRICO DANZER, UWE SCHWARZ, N. SCOTT ADZICK, ALAN W. FLAKE, AND HOLLY L. HEDRICK \\ The Children's Institute for Surgical Science and the Center for Fetal Diagnosis and Treatment, The Children's Hospital of Philadelphia, \\ Philadelphia, Pennsylvania, 19104
}

\begin{abstract}
Fetal tracheal occlusion (TO) accelerates lung growth and can reverse severe lung hypoplasia associated with diaphragmatic hernia $(\mathrm{DH})$, however, lung compliance $(\mathrm{CL})$ and respiratory gas exchange remain abnormal. We determined the individual and combined effects of prenatal glucocorticoids (GC) and exogenous surfactant therapy $(\mathrm{S})$ on postnatal pulmonary function in lambs with $\mathrm{DH}$ that underwent prolonged TO. DH was created in 22 fetal sheep at $65 \mathrm{~d}$ of gestation and TO performed at $110 \mathrm{~d}$. Eleven DH/TO animals received prenatal GC (betamethasone, $0.5 \mathrm{mg} / \mathrm{kg}$ ) $48 \mathrm{~h}$ before delivery; six GC-treated and five non-GC lambs were administered surfactant (Infasurf, $3 \mathrm{mg} / \mathrm{kg}$ ) at birth. Six sham-operated lambs served as controls. Lambs were delivered at $139 \mathrm{~d}$ gestation and ventilated for $2 \mathrm{~h}$. GC or surfactant therapy alone significantly improved respiratory gas exchange, $\mathrm{C}_{\mathrm{L}}$, and ventilatory efficiency index. Total lung capacity was normalized only in DH/TO lambs that received both GC and S. (Pediatr Res 60: 131-135, 2006)
\end{abstract}

$\mathrm{P}^{\mathrm{r}}$ renatal TO induces rapid lung growth, and can reverse severe lung growth deficits. During normal fetal development, the future airspaces are filled with liquid that is actively secreted by the pulmonary epithelium and leaves the lungs via the trachea $(1,2)$. When the fetal trachea is occluded, liquid accumulates within the lung lumen, leading to increased levels of lung tissue stretch and accelerated lung growth $(3,4)$. Morphologically, the lung growth response following TO is characterized by alveolar multiplication (5-7) and expansion of the arterial vasculature $(8,9)$. Prolonged fetal TO (i.e. $>10$ d) has unfavorable effects upon lung development including an increase in alveolar wall thickness $(3,10)$, decreased AE2 cell density $(3,7,11)$ and reduced synthesis of pulmonary surfactant (12). Functionally, lambs that have undergone prolonged periods of TO (4 wk) to reverse fetal lung hypoplasia demonstrate low $\mathrm{C}_{\mathrm{L}}$ and are difficult to ventilate despite restoration of lung growth $(3,12,13)$. Although reestablishing tracheal liquid flow after a period of prolonged $\mathrm{TO}$ (i.e. temporary $\mathrm{TO}$ ) results in recovery of $\mathrm{AE} 2$ cell density

Received January 10, 2005; accepted March 21, 2006.

Correspondence: Marcus G. Davey, Ph.D., Abramson 1116F, 3615 Civic Center Blvd., Philadelphia, PA 19104; e-mail: daveym@email.chop.edu

This study was funded by the March of Dimes Basil O'Connor Award (H.L.H.).

DOI: 10.1203/01.pdr.0000227509.94069.ae and surfactant protein mRNA expression $(3,14)$, CL remains low and respiratory gas exchange is severely impaired (3).

In newborns with incompliant lungs, therapies that increase $\mathrm{C}_{\mathrm{L}}$ can significantly improve respiratory gas exchange, reducing respiratory morbidity and mortality. Fetal exposure to GC improved lung compliance and arterial oxygenation of lambs born preterm $(15,16)$. The increase in $\mathrm{C}_{\mathrm{L}}$ following fetal GC may involve a reduction in alveolar wall thickness and subsequent increase in aerated parenchyma $(17,18)$, and increased surfactant synthesis (19). Given the beneficial effects of prenatal GC upon $\mathrm{CL}_{\mathrm{L}}$ and respiratory gas exchange, the primary aim of this study was to determine whether prenatal exposure to $\mathrm{GC}$ could improve $\mathrm{C}_{\mathrm{L}}$ and respiratory function in lambs that underwent prolonged TO to reverse an existing lung hypoplasia. An alternative therapy that improves respiratory function in newborn with low $C_{L}$ is exogenous surfactant. Surfactant is a lipid-protein mixture synthesized and secreted by AE2 cells, which reduces surface tension forces at the air-liquid interface and prevents atelectasis at low lung volumes. As prolonged TO results in surfactant deficiency, a secondary aim was to determine whether surfactant replacement therapy improved $\mathrm{C}_{\mathrm{L}}$ and gas exchange in lambs that underwent TO for treatment of fetal lung hypoplasia. In addition, we examined the combined effects of prenatal GC and postnatal surfactant therapy upon respiratory function following prolonged fetal TO.

\section{MATERIALS AND METHODS}

Experimental protocols were approved by the local Institutional Animal Care and Use Committee and followed guidelines set forth in the National Institutes of Health, Guide for the Care and Use of Laboratory Animals.

Surgical procedures. Detailed surgical procedures are described elsewhere (3). Briefly, left-sided $\mathrm{DH}$ was created in 22 fetal lambs at $65 \mathrm{~d}$ gestational age and TO performed at $110 \mathrm{~d}$. Eleven of $22 \mathrm{DH} / \mathrm{TO}$ fetuses were exposed to GC (Celestone Chronodose, Schering Plough, New South Wales, Australia; $0.5 \mathrm{mg} / \mathrm{kg}$ body weight) via maternal intramuscular injection, $48 \mathrm{~h}$ before cesarean delivery. This dose of GC consistently improves pulmonary structure and function in preterm sheep $(18,20)$. A group of animals which underwent

Abbreviations: AE2, alveolar epithelial type 2; $\mathbf{C}_{\mathbf{L}}$, lung compliance; DH, diaphragmatic hernia; GC, glucocorticoids; PEEP, positive end-expiratory pressure; PIP, peak inspiratory pressure; PVR, pulmonary vascular resistance S, surfactant; TLC, total lung capacity; TO, tracheal occlusion; VEI, ventilation efficiency index 
sham fetal surgery for DH (thoracotomy without diaphragm incision) and TO (passing suture under the trachea) served as controls $(n=6)$.

Resuscitation of lambs. Between 139 and $140 \mathrm{~d}$ gestational age, lambs were partially delivered by cesarean section and catheters implanted into the carotid artery and jugular vein. An endotracheal tube was inserted through a tracheostomy and liquid suctioned from the airways. Exogenous surfactant (Infasurf, Ony, Inc., Buffalo, NY; $3 \mathrm{~mL} / \mathrm{kg}$ ) was administered to six GCtreated and five non-GC-treated DH/TO lambs. After dividing the umbilical cords, lambs were dried, moved to a heated crib, and ventilated with $100 \%$ oxygen for $2 \mathrm{~h}$ (3). Initial ventilator settings were 60 breaths/min, $30 \mathrm{~cm} \mathrm{H}_{2} \mathrm{O}$ PIP, $4 \mathrm{~cm} \mathrm{H}_{2} \mathrm{O}$ PEEP, $0.25 \mathrm{~s}$ inspiratory time, and $0.3 \mathrm{~s}$ pause time. Arterial $\mathrm{PO}_{2}$ and $\mathrm{PCO}_{2}$ were measured at regular intervals; respiratory rate and pressures were adjusted, if feasible, to maintain $\mathrm{PCO}_{2}$ between 35 and $45 \mathrm{~mm} \mathrm{Hg}$.

Animal groups. There were five animal groups: 1$)$ sham operated $(n=6)$, 2) lambs with $\mathrm{DH}$ that underwent $\mathrm{TO}(\mathrm{DH} / \mathrm{TO}, n=6), 3) \mathrm{DH} / \mathrm{TO}$ animals that received only prenatal GC (DH/TO $+\mathrm{GC}, n=5), 4) \mathrm{DH} / \mathrm{TO}$ animals that received only exogenous surfactant $(\mathrm{DH} / \mathrm{TO}+\mathrm{S}, n=5)$, and 5) $\mathrm{DH} / \mathrm{TO}$ animals that received both treatments ( $\mathrm{DH} / \mathrm{TO}+\mathrm{GC}+\mathrm{S}, n=6)$. Groups 1 and 2 were from a previous study (3).

Postmortem. Body and lung weights were recorded, and pressure-volume curves performed on excised lungs. Portions of left lung were oven dried at $65^{\circ} \mathrm{C}$ for $7 \mathrm{~d}$ to determine pulmonary water content and dry lung weight.

Statistical analysis. Arterial $\mathrm{PO}_{2}, \mathrm{PCO}_{2}$, inspiratory pressure (PIP - PEEP) and respiratory rate were grouped into time intervals, and analyzed using a between-group (treatment) repeated measures (time) ANOVA. VEI was calculated according to the following equation: $\mathrm{VEI}=3800 /\left(\Delta \mathrm{P} \cdot \mathrm{f} \cdot \mathrm{PaCO}_{2}\right)$, where $\Delta \mathrm{P}=\mathrm{PIP}-\mathrm{PEEP}$ and $\mathrm{f}=$ respiratory rate, and analyzed using an ANOVA (as described above). TLC (measured at an airway pressure of $40 \mathrm{~cm}$ $\mathrm{H}_{2} \mathrm{O}$ ), area of the pressure-volume hysteresis curve, slope of the deflation limb of the pressure-volume curve measured at mid-lung volume $\left(20-15 \mathrm{~cm} \mathrm{H}_{2} \mathrm{O}\right)$ and low-lung volume $\left(10-5 \mathrm{~cm} \mathrm{H}_{2} \mathrm{O}\right)$, dry lung-to-body weight ratio, and pulmonary water content were compared between groups using a one-way ANOVA. Post hoc analysis was performed using least significant difference test. Significance was accepted at $p<0.05$. All data are presented as the mean \pm SEM.

\section{RESULTS}

Arterial blood gas tensions of $\mathrm{O}_{2}$ and $\mathrm{CO}_{2}$. Mean values of arterial $\mathrm{Po}_{2}$ throughout the 2-h resuscitation were lower in $\mathrm{DH} / \mathrm{TO}$ lambs $(25.1 \pm 4.3 \mathrm{~mm} \mathrm{Hg})$ compared with sham animals (418.8 $\pm 26.9 \mathrm{~mm} \mathrm{Hg}$ ) (Fig. 1). Arterial oxygenation improved significantly with either prenatal glucocorticoid therapy $(\mathrm{DH} / \mathrm{TO}+\mathrm{GC}, 239.3 \pm 33.7 \mathrm{~mm} \mathrm{Hg})$ or exogenous surfactant therapy $(\mathrm{DH} / \mathrm{TO}+\mathrm{S}, 491.8 \pm 9.0 \mathrm{~mm} \mathrm{Hg})$; mean $\mathrm{Po}_{2}$ for DH/TO + GC lambs remained lower than sham and $\mathrm{DH} / \mathrm{TO}+\mathrm{S}$ groups. In the $\mathrm{DH} / \mathrm{TO}+\mathrm{GC}+\mathrm{S}$ group, mean $\mathrm{Po}_{2}$ was $435.3 \pm 13.3 \mathrm{~mm} \mathrm{Hg}$, which was not statistically different from sham animals. During the study period, arterial $\mathrm{PCO}_{2}$ was higher in DH/TO lambs compared with sham animals $(87.7 \pm 3.6 \mathrm{~mm} \mathrm{Hg}$ and $61.4 \pm 3.3$, respectively; group means). Mean values of $\mathrm{PCO}_{2}$ for $\mathrm{DH} / \mathrm{TO}+\mathrm{S}(55.8 \pm 3.1 \mathrm{~mm}$ $\mathrm{Hg}), \mathrm{DH} / \mathrm{TO}+\mathrm{GC}(57.5 \pm 4.2)$, and $\mathrm{DH} / \mathrm{TO}+\mathrm{GC}+\mathrm{S}(51.3$ $\pm 2.7 \mathrm{~mm} \mathrm{Hg}$ ) lambs were not different from sham animals.

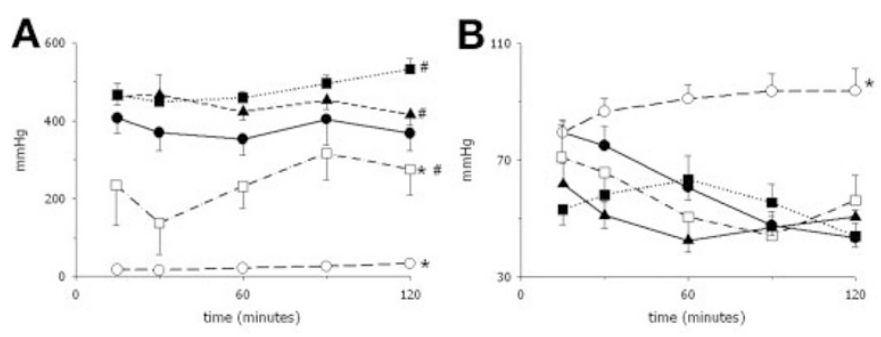

Figure 1. Arterial blood gas tensions of oxygen $\left(\mathrm{PaO}_{2}\right)(A)$ and carbon dioxide $\left(\mathrm{PaCO}_{2}\right)(B)$ for sham $(\bullet)$, DH/TO $(O), \mathrm{DH} / \mathrm{TO}+\mathrm{S}(\boldsymbol{\square}), \mathrm{DH} / \mathrm{TO}+$ $\mathrm{GC}(\square)$ and $\mathrm{DH} / \mathrm{TO}+\mathrm{S}+\mathrm{GC}(\boldsymbol{\Lambda})$ lambs measured during $2 \mathrm{~h}$ of mechanical ventilation. ${ }^{*} p<0.05$ compared with sham, $\dagger p<0.05$ compared with DH/TO.
Ventilation parameters and VEI. Inspiratory pressure, calculated as PIP minus positive end expiratory pressure (PEEP), and respiratory rate were higher in DH/TO lambs (23.9 \pm 0.3 $\mathrm{cm} \mathrm{H}_{2} \mathrm{O}$ and $83.2 \pm 3.2$ breaths $/ \mathrm{min}$ ) than sham animals (19.3 $\pm 0.5 \mathrm{~cm} \mathrm{H}_{2} \mathrm{O}$ and $51.9 \pm 1.3$ breaths/min) (Fig. 2). For $\mathrm{DH} / \mathrm{TO}+\mathrm{GC}$ lambs, mean inspiratory pressure $(22.2 \pm 0.6$ $\mathrm{cm} \mathrm{H}_{2} \mathrm{O}$ ) was higher than sham, and lower than DH/TO animals. There was no statistical difference for mean inspiratory pressure and inspiratory rate for either $\mathrm{DH} / \mathrm{TO}+\mathrm{S}$ $\left(18.1 \pm 0.5 \mathrm{~cm} \mathrm{H}_{2} \mathrm{O}\right.$ and $57.4 \pm 2.6$ breaths $/ \mathrm{min}$ ) or DH/TO $+\mathrm{GC}+\mathrm{S}\left(18.2 \pm 0.4 \mathrm{~cm} \mathrm{H}_{2} \mathrm{O}\right.$ and $55.0 \pm 1.6$ breaths $\left./ \mathrm{min}\right)$ when compared with sham group. The VEI during the study period was lower in DH/TO lambs $(0.025 \pm 0.002 \mathrm{~mL} / \mathrm{mm}$ $\mathrm{Hg} / \mathrm{kg})$ than sham animals $(0.078 \pm 0.007 \mathrm{~mL} / \mathrm{mm} \mathrm{Hg} / \mathrm{kg})$. Mean values of VEI for DH/TO $+\mathrm{S}$, DH/TO $+\mathrm{GC}$, and $\mathrm{DH} / \mathrm{TO}+\mathrm{GC}+\mathrm{S}$ lambs $(0.080 \pm 0.010,0.0571 \pm 0.008$, and $0.084 \pm 0.007 \mathrm{~mL} / \mathrm{mm} \mathrm{Hg} / \mathrm{kg}$, respectively) were higher than DH/TO lambs and not significantly different from sham group.

Pressure-volume curve analysis. TLC, measured at $40 \mathrm{~cm}$ $\mathrm{H}_{2} \mathrm{O}$ airway pressure, was significantly reduced in DH/TO lambs compared with sham group (42.3 \pm 8.2 versus $160.7 \pm$ $10.4 \mathrm{~mL} / 100 \mathrm{~g}$ wet lung) (Figs. 3 and 4). Treatment with either prenatal GC or exogenous surfactant significantly improved lung compliance $(97.2 \pm 9.8$ and $115.9 \pm 26.0 \mathrm{~mL} / 100 \mathrm{~g}$ wet lung), however, mean values remained lower than sham group. Lung compliance in $\mathrm{DH} / \mathrm{TO}+\mathrm{GC}+\mathrm{S}$ lambs was $166.0 \pm 6.9 \mathrm{~mL} / 100 \mathrm{~g}$ wet lung, and not different from sham animals. The area of the pressure-volume hysteresis curve was significantly lower in $\mathrm{DH} / \mathrm{TO}$ lambs than sham group (4.0 \pm 0.9 and $17.4 \pm 1.1 \mathrm{~mL} / \mathrm{g}$ wet lung). Prenatal glucocorticoid therapy did not significantly improve mean values (DH/TO + GC; $6.0 \pm 0.5 \mathrm{~mL} / \mathrm{g}$ wet lung), whereas exogenous surfactant increased the area of the hysteresis curve $(\mathrm{DH} / \mathrm{TO}+\mathrm{S}$, $11.1 \pm 3.3 \mathrm{~mL} / \mathrm{g}$ wet lung). Mean values for $\mathrm{DH} / \mathrm{TO}+\mathrm{S}$ and $\mathrm{DH} / \mathrm{TO}+\mathrm{GC}+\mathrm{S}(13.9 \pm 0.8 \mathrm{~mL} / \mathrm{g}$ wet lung) were not different from sham group. The slope of the deflation curve, measured between 10 and $5 \mathrm{~cm} \mathrm{H}_{2} \mathrm{O}$, was reduced in DH/TO compared with sham group $(1.9 \pm 0.4$ and $8.9 \pm 1.5 \mathrm{~mL} / \mathrm{g}$ wet lung/cm $\mathrm{H}_{2} \mathrm{O}$, respectively). Mean values were increased by exogenous surfactant therapy, but not by prenatal GC $\left(5.6 \pm 1.5\right.$ and $3.8 \pm 1.2 \mathrm{~mL} / \mathrm{g}$ wet lung $/ \mathrm{cm} \mathrm{H}_{2} \mathrm{O}$, respectively). The slope of the deflation curve for both $\mathrm{DH} / \mathrm{TO}+\mathrm{S}$ and $\mathrm{DH} / \mathrm{TO}+\mathrm{GC}+\mathrm{S}\left(9.2 \pm 1.3 \mathrm{~mL} / \mathrm{g}\right.$ wet lung/cm $\left.\mathrm{H}_{2} \mathrm{O}\right)$ were not significantly different from sham group. The slope of the deflation curve between 20 and $15 \mathrm{~cm} \mathrm{H}_{2} \mathrm{O}$ was significant increased by GC and S compared with $\mathrm{DH} / \mathrm{TO}$ alone.

Lung to body weight ratio and pulmonary water content. Body weight-adjusted values of dry lung weight were not statistically different between groups: sham, $3.0 \pm 0.2 \mathrm{~g} / \mathrm{kg}$; $\mathrm{DH} / \mathrm{TO}, 4.4 \pm 0.5 \mathrm{~g} / \mathrm{kg} ; \mathrm{DH} / \mathrm{TO}+\mathrm{S}, 3.6 \pm 0.5 \mathrm{~g} / \mathrm{kg} ; \mathrm{DH} / \mathrm{TO}$ $+\mathrm{GC}, 3.6 \pm 0.5 \mathrm{~g} / \mathrm{kg} ; \mathrm{DH} / \mathrm{TO}+\mathrm{GC}+\mathrm{S}, 3.4 \pm 0.2 \mathrm{~g} / \mathrm{kg}$ (Fig. 5). Pulmonary water content was significantly higher in all treatment groups $(\mathrm{DH} / \mathrm{TO}, 9.2 \pm 0.6 ; \mathrm{DH} / \mathrm{TO}+\mathrm{S}$, $8.7 \pm 0.5 ; \mathrm{DH} / \mathrm{TO}+\mathrm{GC}, 7.7 \pm 0.8 ; \mathrm{DH} / \mathrm{TO}+\mathrm{GC}+\mathrm{S}, 7.5$ $\pm 0.9 \mathrm{~mL} / \mathrm{g}$ dry lung) compared with sham group $(5.7 \pm 0.3$ $\mathrm{mL} / \mathrm{g}$ dry lung). 

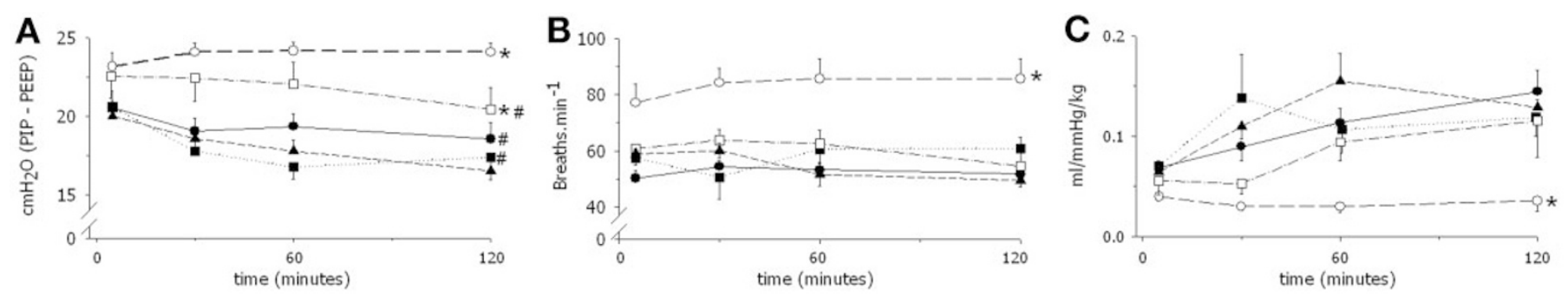

Figure 2. Inspiratory pressure $(A)$ and respiratory rate $(B)$ required to maintain $\mathrm{PaCO}_{2}$ between 35 and $45 \mathrm{~mm} \mathrm{Hg}$, and VEI $(C)$ for sham $(\bullet)$, DH/TO $(O)$, $\mathrm{DH} / \mathrm{TO}+\mathrm{S}(\boldsymbol{\square}), \mathrm{DH} / \mathrm{TO}+\mathrm{GC}(\square)$, and DH/TO $+\mathrm{S}+\mathrm{GC}(\boldsymbol{\Delta})$ lambs measured during the resuscitation study. $* p<0.05$ compared with sham, $\uparrow p<0.05$ compared with $\mathrm{DH} / \mathrm{TO}$.

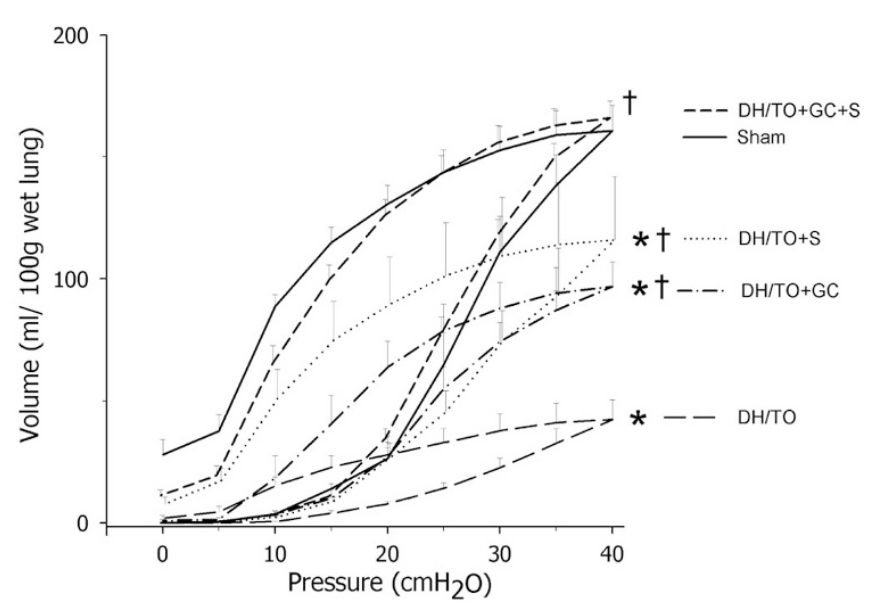

Figure 3. Air-filled pressure volume curves performed on excised lungs for sham. $* p<0.05$ compared with sham, $\dagger p<0.05$ compared with DH/TO.

\section{DISCUSSION}

In lambs with $\mathrm{DH}$ that underwent prolonged fetal TO, prenatal exposure to GC or surfactant replacement therapy significantly improved $\mathrm{CL}_{\mathrm{L}}$ and respiratory gas exchange. Furthermore, the level of ventilatory support required to maintain normocarbia, was lower in $\mathrm{DH} / \mathrm{TO}$ lambs that received either GC or exogenous surfactant. When administered independently, GC and surfactant increased TLC (measured at $40 \mathrm{~cm}$ $\mathrm{H}_{2} \mathrm{O}$ ). However, normal values of TLC were only achieved in $\mathrm{DH} / \mathrm{TO}$ lambs that received combined treatments (i.e. DH/TO $+\mathrm{GC}+\mathrm{S}$ group). Pulmonary water content of postnatal lambs is increased by prolonged TO (3), which was not ameliorated by individual or combined GC/S therapy. Our data indicate that combined GC and surfactant therapy may improve postnatal respiratory function in near-term human fetuses undergoing prolonged TO.

During fetal life, mechanical factors play a pivotal role in regulating lung growth $(1,2)$ and differentiation of alveolar epithelium $(3,21,22)$. Fetal TO increases the levels of lung tissue stretch leading to proliferation of both epithelial and mesenchymal compartments (23), greatly increasing the gas exchange surface area. In the ovine surgical model of DH, which results in a $>60 \%$ reduction in lung-to-body weight ratio, we found that $4 \mathrm{wk}$ of TO consistently restored fetal lung growth. However, surfactant protein mRNA expression and the density of surfactant protein B-positive epithelial cells (i.e. AE2 cells) were markedly reduced (3). It is now evident that $\mathrm{TO}$ accelerates differentiation of AE2 into alveolar type 1

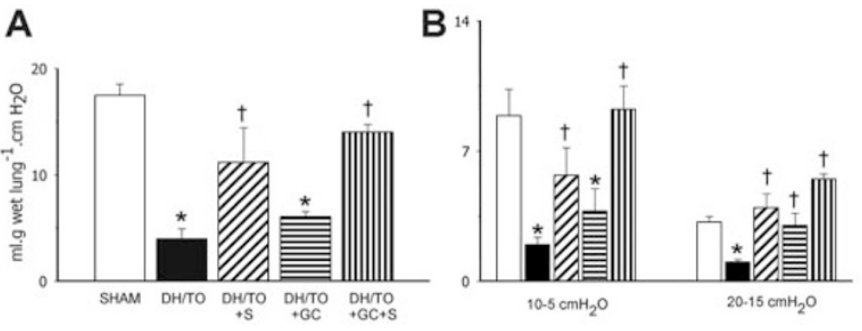

Figure 4. Area of the hysteresis curve $(A)$ and slope of the deflation curve $(B)$ measured at low lung volume (left) and mid-lung volume (right) for Sham $(\square), \mathrm{DH} / \mathrm{TO}(\mathbf{\square}), \mathrm{DH} / \mathrm{TO}+\mathrm{S}(\mathbb{2}), \mathrm{DH} / \mathrm{TO}+\mathrm{GC}($ 目) and DH/TO + S + GC (畂). Designation of animal groups is the same for all plots. $* p<0.05$ compared with sham, $\dagger p<0.05$ compared with DH/TO.
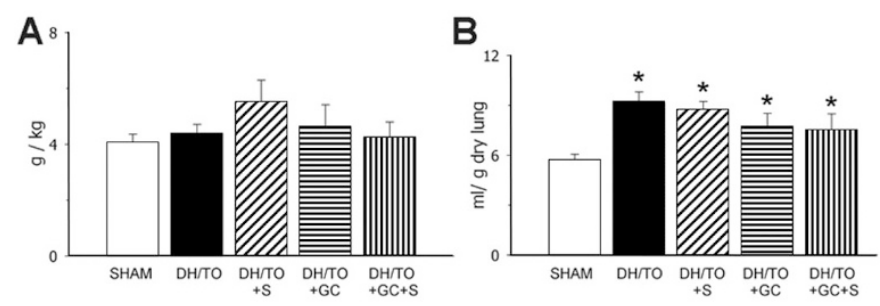

Figure 5. Dry lung-to-body weight ratio $(A)$ and pulmonary water content $(B)$ for sham $(\square), \mathrm{DH} / \mathrm{TO}(\boldsymbol{\square}), \mathrm{DH} / \mathrm{TO}+\mathrm{S}(\mathbb{Q}), \mathrm{DH} / \mathrm{TO}+\mathrm{GC}($ 回), and DH/TO $+\mathrm{S}+\mathrm{GC}(\mathbb{W})$. Values are expressed at mean \pm SEM. $* p<0.05$ compared with sham.

cells $(21,22)$. Despite normal lung size, lambs born at term that underwent 4 wk of TO for treatment of DH-associated lung hypoplasia demonstrated impaired respiratory gas exchange and abnormally low CL. Restoring normal tracheal liquid flow after a period of TO (i.e. temporary TO) decreases the levels of lung tissue stretch, leading to increased expression of surfactant proteins and density of AE2 cells (3). However, respiratory gas exchange and $C_{L}$ remained abnormal in lambs with DH that underwent temporary TO, possibly due to impaired synthesis and/or secretion of surfactant (11).

The rationale for prenatal GC therapy in fetal sheep undergoing $\mathrm{TO}$ was to improve postnatal $\mathrm{C}_{\mathrm{L}}$ and promote alveolar gas exchange. In addition to reducing the ventilation efficiency index (VEI) in DH/TO lambs, a single maternal dose of GC significantly increased $\mathrm{C}_{\mathrm{L}}$, measured at mid-lung volume (20-15 $\mathrm{cm} \mathrm{H}_{2} \mathrm{O}$ ), and TLC. During the resuscitation study, tidal volumes were significantly higher in GC treated versus non-GC-treated DH/TO lambs at equal end-inspiratory pressure. More importantly, arterial oxygenation and $\mathrm{CO}_{2}$ levels were markedly improved; albeit, values of arterial $\mathrm{Po}_{2}$ and 
$\mathrm{PCO}_{2}$ throughout the resuscitation study were lower than sham animals. Certain aspects of pulmonary function including area of the hysteresis curve and $\mathrm{C}_{\mathrm{L}}$ at low lung volumes $(10-5 \mathrm{~cm}$ $\mathrm{H}_{2} \mathrm{O}$ ), remained abnormal in DH/TO lambs treated only with prenatal GC. Two factors that predominantly determine $\mathrm{C}_{\mathrm{L}}$ of the air-filled lung, both of which are influenced by prenatal GC, are distensibility of lung structural components (i.e. the elastin/collagen framework), and synthesis of alveolar surfactant. We are unable to determine the extent to which prenatal $\mathrm{GC}$ alters the contribution of these two factors in our DH/TO + GC lambs. Pressure-volume curves of liquid-filled lungs, which eliminate surface tension forces and removes the influence of surfactant, and molecular analysis of surfactant would be required. Other investigators have shown that brief exposure $(24 \mathrm{~h})$ to prenatal GC induces a mild increase in density of cells expressing surfactant protein-C mRNA in lambs that underwent prolonged TO (24). These data support the premise that prenatal GC may influence alveolar epithelial cell phenotype during periods of increased levels of lung tissue stretch.

Decreased PVR, resulting from changes in pulmonary arterial structure and/or enhanced responsiveness to endogenous vasodilators, may have contributed to improved respiratory gas exchange in GC-treated fetuses. In fetal rats with $\mathrm{CDH}$, exposure to dexamethasone significantly decreased medial wall thickness of pre- and intraacinar vessels (25). Increased luminal diameter due to a reduction in medial wall thickness would be expected to lower PVR. In lambs with lung hypoplasia, prenatal GC significantly lowered the already elevated PVR (data presented as an abstract; Suzuki et al. 2006 Pediatric Academic Societies, San Francisco) an effect that may be related to enhanced vasodilation to catecholamines (26).

The secondary aim of this study was to determine the role of exogenous surfactant therapy in DH/TO lambs with, and without, prenatal GC therapy. Our data demonstrate that surfactant therapy alone (i.e. $\mathrm{DH} / \mathrm{TO}+\mathrm{S}$ ) significantly improved all measurements of respiratory function (e.g. gas exchange, compliance), and reduced the respiratory workload compared with untreated DH/TO lambs. The improvement in arterial oxygenation in our DH/TO lambs treated with exogenous surfactant is in agreement with data from O'Toole and coworkers (13); these authors also demonstrated normalization of pulmonary blood flow in DH/TO lambs treated with exogenous surfactant. In contrast, Butter et al. (27) found that exogenous surfactant administered to DH/TO lambs did not improve gas exchange or ventilation efficiency index. Discrepancies between studies are difficult to explain. Administration of exogenous surfactant can transiently impair gas exchange due to airway obstruction. Hence, the higher volumes of surfactant used in the study by Butter $e t$ al., compared with that used in our current study and that by O'Toole et al. ( $5 \mathrm{~mL} / \mathrm{kg}$ versus 3 $\mathrm{mL} / \mathrm{kg}$, respectively), may account for discrepant findings between studies. Another possibility is that lambs were delivered at an earlier gestational age in the study by Butter et al. (136 d) compared with our current study (139-140 d).

Clinically, exogenous surfactant therapy did not appear to dramatically improve respiratory gas exchange in infants that underwent prolonged TO for treatment of severe DH $(28,29)$. It is important to consider that surfactant preparations used in human TO studies (Survanta and Exosurf) are devoid of surfactant associated proteins that appear to be a crucial factor in their surface activity ability to improve pressure-volume mechanics (30). As prolonged TO significantly reduces synthesis of both lipid (31) and protein components of surfactant $(3,32)$, exogenous surfactant containing surfactant-associated proteins may be more ideal for this patient population. Clearly, however, other important factors including duration and timing of TO, variable fetal lung growth response, prematurity of birth, and abnormal lung pathology $(28,29,33)$ reduce $\mathrm{C}_{\mathrm{L}}$ and increase respiratory morbidity and mortality in human infants treated with prenatal TO.

An interesting finding of our study is that TLC (measured at $40 \mathrm{~cm} \mathrm{H}_{2} \mathrm{O}$ ) was normalized only in those lambs that received both prenatal GC and postnatal surfactant therapy (i.e. DH/TO $+\mathrm{GC}+\mathrm{S})$ group. The summative effects of combined therapies upon $\mathrm{C}_{\mathrm{L}}$ are likely due to $\mathrm{GC}$-induced increase in tissue distensibility (surfactant independent) and a reduction in alveolar surface tension forces (surfactant dependent). In preterm monkeys at $80 \%$ of gestation, maternal intramuscular administration of GC increased lung capacity of saline-filled lungs. With saline filling of the lungs, there are no significant surface tension forces and hence the increase in lung capacity after prenatal GC is contributed in part by alteration in lung connective tissue characteristics (34). The capacity for prenatal GC to rapidly increase alveolar volume and decrease alveolar wall thickness $(16,18)$ may also lead to higher values of TLC in our GC-treated lambs.

Neither prenatal GC nor exogenous surfactant corrected the increased pulmonary water content in lambs that underwent TO. In a previous study, we found that re-establishing normal tracheal flow for $10 \mathrm{~d}$ after a period of prolonged TO restored surfactant protein mRNA and resulted in normal values of pulmonary water content (3). As pulmonary surfactant helps maintain the alveoli relatively "dry" by lowering surface tension forces and preventing fluid transudation from capillaries (35), we hypothesized that surfactant replacement therapy after prolonged TO would result in normal values of pulmonary water content. This hypothesis is not supported by results of our current study. Pulmonary water content remained elevated in $\mathrm{DH} / \mathrm{TO}+\mathrm{S}$ lambs, even when data were adjusted for volume of exogenous surfactant instilled into the airway. Pulmonary epithelial liquid absorption is decreased by TO (36), possibly via altering gene expression of molecular pumps and/or ion channels involved in liquid clearance from the airspaces after birth (37). Regardless, increased pulmonary water content in GC- and surfactant-treated lambs does not seriously impact early neonatal gas exchange.

We acknowledge the minor limitations of our current study. Firstly, lambs were ventilated with $100 \%$ oxygen throughout the resuscitation study, preventing a more detailed assessment of alveolar gas exchange. Ideally, we could have lowered the $\mathrm{FiO}_{2}$ and determined the level at which arterial $\mathrm{Po}_{2}$ was within physiologic levels (between $80-100 \mathrm{~mm} \mathrm{Hg}$ ) for each of the treatment groups. It is possible that at a lower $\mathrm{FiO}_{2}$, arterial oxygenation of $\mathrm{DH} / \mathrm{TO}+\mathrm{S}$ and $\mathrm{DH} / \mathrm{TO}+\mathrm{GC}+\mathrm{S}$ groups are lower than normal, and would be indicative of abnormal gas exchange. Secondly, we could have extended the duration 
of the resuscitation study beyond $2 \mathrm{~h}$ after delivery to obtain additional longitudinal data. However, other groups investigating the effects of $\mathrm{TO}$ in the ovine model of $\mathrm{DH}$ who performed 4 and $8 \mathrm{~h}$ resuscitation studies $(13,27)$, found that early postnatal changes in gas exchange and PVR occurred within the first $2 \mathrm{~h}$ after birth; only minor changes in postnatal lung function occurred thereafter. Finally, we could have obtained lung liquid samples at the time of delivery to determine the effects of prenatal GC, during periods of increased lung expansion induced by TO, upon surfactant content and quality. Combined with data from liquid-filled pressurevolume curves, we could further understand the physiologic consequences of prenatal GC on surfactant dependent and independent mechanisms during prolonged TO.

\section{CONCLUSION}

Our data demonstrate that prenatal GC and exogenous surfactant therapy significantly improve respiratory function in lambs that have undergone prolonged TO for treatment of severe lung hypoplasia. The greatest improvement in pressurevolume characteristics and TLC was observed with combined GC and surfactant therapy, more than with either therapy alone. In fetal sheep, the benefits of prenatal GC, with respect to postnatal lung function, were greatest when administered later, rather than earlier in gestation (38). The gestational age at delivery and duration of TO in human fetuses with severe DH has increased significantly with the development of minimally invasive techniques. Single-dose prenatal GC may benefit near-term fetuses that demonstrate increased lung growth in response to prolonged TO, with improvement in postnatal respiratory function and a reduction in postnatal morbidity and mortality. A controlled randomized trial is required to test this hypothesis.

\section{REFERENCES}

1. Harding R, Hooper SB 1996 Regulation of lung expansion and lung growth before birth. J Appl Physiol 81:209-224

2. Hooper SB, Harding R 1995 Fetal lung liquid: a major determinant of the growth and functional development of the fetal lung. Clin Exp Pharmacol Physiol 22:235-247

3. Davey MG, Hedrick HL, Bouchard S, Mendoza JM, Schwarz U, Adzick NS, Flake AW 2003 Temporary tracheal occlusion in fetal sheep with lung hypoplasia does not improve postnatal lung function. J Appl Physiol 94:1054-1062

4. Nardo L, Hooper SB, Harding R 1998 Stimulation of lung growth by tracheal obstruction in fetal sheep: relation to luminal pressure and lung liquid volume. Pediatr Res 43:184-190

5. DiFiore JW, Fauza DO, Slavin R, Peters CA, Fackler JC, Wilson JM 1994 Experimental fetal tracheal ligation reverses the structural and physiological effects of pulmonary hypoplasia in congenital diaphragmatic hernia. J Pediatr Surg 29:248256 discussion 256-247.

6. Lipsett J, Cool JC, Runciman SI, Ford WD, Kennedy JD, Martin AJ 1998 Effect of antenatal tracheal occlusion on lung development in the sheep model of congenital diaphragmatic hernia: a morphometric analysis of pulmonary structure and maturity. Pediatr Pulmonol 25:257-269

7. Benachi A, Chailley-Heu B, Delezoide AL, Dommergues M, Brunelle F, Dumez Y, Bourbon JR 1998 Lung growth and maturation after tracheal occlusion in diaphragmatic hernia. Am J Respir Crit Care Med 157:921-927

8. DiFiore JW, Fauza DO, Slavin R, Wilson JM 1995 Experimental fetal tracheal ligation and congenital diaphragmatic hernia: a pulmonary vascular morphometric analysis. J Pediatr Surg 30:917-923, discussion 923-914

9. Kanai M, Kitano Y, von Allmen D, Davies P, Adzick NS, Flake AW 2001 Fetal tracheal occlusion in the rat model of nitrofen-induced congenital diaphragmatic hernia: tracheal occlusion reverses the arterial structural abnormality. J Pediatr Surg 36:839-845

10. Papadakis K, De Paepe ME, Tackett LD, Piasecki GJ, Luks FI 1998 Temporary tracheal occlusion causes catch-up lung maturation in a fetal model of diaphragmatic hernia. J Pediar Surg 33:1030-1037
11. Bratu I, Flageole H, Laberge JM, Possmayer F, Harbottle R, Kay S, Khalife S, Piedboeuf B 2001 Surfactant levels after reversible tracheal occlusion and prenatal steroids in experimental diaphragmatic hernia. J Pediatr Surg 36:122-127

12. O'Toole SJ, Sharma A, Karamanoukian HL, Holm B, Azizkhan RG, Glick PL 1996 Tracheal ligation does not correct the surfactant deficiency associated with congenital diaphragmatic hernia. J Pediatr Surg 31:546-550

13. O'Toole SJ, Karamanoukian HL, Irish MS, Sharma A, Holm BA, Glick PL 1997 Tracheal ligation: the dark side of in utero congenital diaphragmatic hernia treatment. J Pediatr Surg 32:407-410

14. Bin Saddiq W, Piedboeuf B, Laberge JM, Gamache M, Petrov P, Hashim E, Manika A, Chen MF, Belanger S, Piuze G 1997 The effects of tracheal occlusion and release on type II pneumocytes in fetal lambs. J Pediatr Surg 32:834-838

15. Jobe AH, Polk D, Ikegami M, Newnham J, Sly P, Kohen R, Kelly R 1993 Lung responses to ultrasound-guided fetal treatments with corticosteroids in preterm lambs. J Appl Physiol 75:2099-2105

16. Pinkerton KE, Willet KE, Peake JL, Sly PD, Jobe AH, Ikegami M 1997 Prenatal glucocorticoid and T4 effects on lung morphology in preterm lambs. Am J Respir Crit Care Med 156:624-630

17. Crone RK, Davies P, Liggins GC, Reid L 1983 The effects of hypophysectomy, thyroidectomy, and postoperative infusion of cortisol or adrenocorticotrophin on the structure of the ovine fetal lung. J Dev Physiol 5:281-288

18. Willet KE, Jobe AH, Ikegami M, Kovar J, Sly PD 2001 Lung morphometry after repetitive antenatal glucocorticoid treatment in preterm sheep. Am J Respir Crit Care Med 163:1437-1443

19. Ballard PL, Ning Y, Polk D, Ikegami M, Jobe AH 1997 Glucocorticoid regulation of surfactant components in immature lambs. Am J Physiol 273:L1048-L1057

20. Rebello CM, Ikegami M, Polk DH, Jobe AH 1996 Postnatal lung responses and surfactant function after fetal or maternal corticosteroid treatment. J Appl Physiol 80:1674-1680

21. Benachi A, Delezoide AL, Chailley-Heu B, Preece M, Bourbon JR, Ryder T 1999 Ultrastructural evaluation of lung maturation in a sheep model of diaphragmatic hernia and tracheal occlusion. Am J Respir Cell Mol Biol 20:805-812

22. Flecknoe SJ, Wallace MJ, Harding R, Hooper SB 2002 Determination of alveolar epithelial cell phenotypes in fetal sheep: evidence for the involvement of basal lung expansion. J Physiol 542:245-253

23. Nardo L, Maritz G, Harding R, Hooper SB 2000 Changes in lung structure and cellular division induced by tracheal obstruction in fetal sheep. Exp Lung Res 26:105-119

24. Kay S, Laberge JM, Flageole H, Richardson S, Belanger S, Piedboeuf B 2001 Use of antenatal steroids to counteract the negative effects of tracheal occlusion in the fetal lamb model. Pediatr Res 50:495-501

25. Okoye BO, Losty PD, Lloyd DA, Gosney JR 1998 Effect of prenatal glucocorticoids on pulmonary vascular muscularisation in nitrofen-induced congenital diaphragmatic hernia. J Pediatr Surg 33:76-80

26. Deruelle P, Houfflin-Debarge V, Magnenant E, Jaillard S, Riou Y, Puech F, Storme L 2003 Effects of antenatal glucocorticoids on pulmonary vascular reactivity in the ovine fetus. Am J Obstet Gynecol 189:208-215

27. Butter A, Bratu I, Flageole H, Laberge JM, Kovacs L, Faucher D, Piedoboeuf B 2005 Fetal tracheal occlusion in lambs with congenital diaphragmatic hernia: role of exogenous surfactant at birth. Pediatr Res 58:689-694

28. Flake AW, Crombleholme TM, Johnson MP, Howell LJ, Adzick NS 2000 Treatment of severe congenital diaphragmatic hernia by fetal tracheal occlusion: clinical experience with fifteen cases. Am J Obstet Gynecol 183:1059-1066

29. Harrison MR, Keller RL, Hawgood SB, Kitterman JA, Sandberg PL, Farmer DL, Lee H, Filly RA, Farrell JA, Albanese CT 2003 A randomized trial of fetal endoscopic tracheal occlusion for severe fetal congenital diaphragmatic hernia N Engl J Med 349:1916-1924

30. Notter RH, Wang Z, Egan EA, Holm BA 2002 Component-specific surface and physiological activity in bovine-derived lung surfactants. Chem Phys Lipids 114:21-34

31. Joe P, Wallen LD, Chapin CJ, Lee CH, Allen L, Han VK, Dobbs LG, Hawgood S, Kitterman JA 1997 Effects of mechanical factors on growth and maturation of the lung in fetal sheep. Am J Physiol 272:L95-L105

32. Lines A, Nardo L, Phillips ID, Possmayer F, Hooper SB 1999 Alterations in lung expansion affect surfactant protein $\mathrm{A}, \mathrm{B}$, and $\mathrm{C}$ mRNA levels in fetal sheep. Am J Physiol 276:L239-L245

33. Heerema AE, Rabban JT, Sydorak RM, Harrison MR, Jones KD 2003 Lung pathology in patients with congenital diaphragmatic hernia treated with fetal surgical intervention, including tracheal occlusion. Pediatr Dev Pathol 6:536546

34. Beck JC, Mitzner W, Johnson JW, Hutchins GM, Foidart JM, London WT, Palmer AE, Scott R 1981 Betamethasone and the rhesus fetus: effect on lung morphometry and connective tissue. Pediatr Res 15:235-240

35. Hawgood S 1997 Surfactant: composition, structure and metabolism. In: Crystal RG, West JB, Weibel ER, Barnes JB (eds) The Lung: Scientific Foundations. LippincottRaven, Philadelphia, pp 557-571

36. Davey MG, Hedrick HL, Mendoza JM, Kanai M, Adzick NS, Flake AW 2002 Pulmonary epithelial liquid absorption, expressed in relation to alveolar surface area, is reduced in fetal lambs following in utero tracheal occlusion. Pediatr Pulmonol $34: 278-286$

37. Liu H, Hooper SB, Armugam A, Dawson N, Ferraro T, Jeyaseelan K, Thiel A, Koukoulas I, Wintour EM 2003 Aquaporin gene expression and regulation in the ovine fetal lung. J Physiol 551:503-514

38. Jobe AH, Newnham J, Willet K, Sly P, Ikegami M 1998 Fetal versus maternal and gestational age effects of repetitive antenatal glucocorticoids. Pediatrics 102:11161125 